\title{
Model $H$ application to determine synergic effects on merger and acquisition
}

\author{
Anna Harumová ${ }^{1, *}$ \\ ${ }^{1}$ University of Economics in Bratislava, Faculty of Business Management, Department of \\ Business Finance, Dolnozemská cesta 1, 85235 Bratislava
}

\begin{abstract}
Synergistic effects arise as effects of joint action based on mergers or acquisitions. Bundling is a common part of the growth strategy. A merger may acquire forms of merger or merger. Acquisition represents the acquisition of the ownership and management value of one company over another. Theory distinguishes in this case from property acquisitions in which the acquisition of the company's assets and capital acquisitions occurs, in which the acquisition of a decisive share in the voting rights of the company is obtained. Reasons for merger and acquisition are to gain more market share, restructure entities, improve balance of payments, and so on. The success of the merger and the acquisition confirms the emergence of a synergy effect. In determining the value of synergies in this article was used newly created Model $\mathrm{H}$, which is based on a valuation of the business enterprise.
\end{abstract}

\section{Introduction}

Over the last decades, natural forms of business integration in the form of mergers, acquisitions, joint ventures, and so on, have grown in the world. The main reasons can be found in the increasing liberalization and globalization of the world economy. Mergers and acquisitions are a well-known and often used term in the global economy. Especially for managers, these business combinations represent a vision of expanding their businesses and thus achieving higher profits, lowering costs, or for them can be the last resort to the crisis. Some experts focusing on the transactions of mergers and acquisitions in the financial sector regularly doubt on the creation of value or even revealing the destruction of values [6]. Several authors have dealt with this issue $[17,15,13]$. The motives for the concentrations are different and the successful execution of this process is much harder than it looks at first glance. Every year, they are appearing in the media about surveys in this field, whose statistics agree that the overwhelming majority of mergers and acquisitions will not reach the predetermined and expected targets [1,14]. For example, KPMG's study shows that only $31 \%$ of all mergers and acquisitions actually generate value [11]. In the English literature the $\mathrm{M} \& \mathrm{M}$ most frequently used matching and $\mathrm{A}$, which is internationally recognized.

\footnotetext{
*Corresponding author: anna.harumova@euba.sk
} 
A special form of M \& A (Mergers and Acquisitions) is the Leveraged Buy-Out (LBO), which differs from the classic $\mathrm{M} \& \mathrm{~A}$ in that a large portion of the purchase price is funded by debt. In practice, the LBO usually takes place by establishing a new company only for this purpose, and it merges with the target company. The owner of the company becomes the investor who bought the company and its managers. As a result of debt financing, a larger burden on capital resources will occur in the new company. In order to evaluate the effects of $\mathrm{M} \& \mathrm{~A}$, we must first be able to evaluate the business as a whole [3].

Business appraisal is an important part of the $\mathrm{M} \& \mathrm{~A}$ effects assessment. It is therefore good to keep in mind a few principles. In particular, it is important to begin with the analysis from the target company, estimate its present value and determine the change in cash flows that this $M$ \& A will bring. Cash flows have a better disclosure value than accounting profit. Economic theory states that although profit is a very valuable indicator, it also hides the same risks of inaccuracies [19]. Before we determine the synergistic effects, we estimate the value of the overall economic effect of the $M \&$ A performed. To obtain its value, a model consisting of the following three steps [4,5]:

1. Separately, the two M \& A enterprises are evaluated using the method discounting expected cash flows

2. The combined value of both companies is calculated, without any effect

from $M \&$ A through a combination of the values obtained in the first step,

3 . The combined value of both enterprises is calculated by including synergies.

The resulting value of all synergies indicates the difference between the combined value of an enterprise, including synergies and synergies. In the professional literature [8] and the practice we can meet the following methods used for the evaluation of the company:

- Methods based on state variables, t. j. methods for determining the cost of equity,

including the book value method and the substance value method,

- Methods based on flow variables, t. j. the yield methods of which include the capitalized

net return method, the discounted value of future financial flows method, the economic added value method,

- Combined methods that combine property and yield methods,

- Exchange benchmarking methods.

Determining the market value of an enterprise poses a complex problem in practice because each company is a unique unit that can not be compared to another company. Effecting a synergistic effect also causes the company's value to be higher than the sum of the individual components of its assets. When assessing a company as a whole, it is necessary to take into account not only the real value of the property, but also its yield potential and prospects for further development of the company, which largely determines the subjective factor.

\section{The current state of the theoretical background of mergers and acquisitions}

A merger can be defined as a process whereby two or more companies with legal personality merge into one company, although no definition of merger can be found in any regulation. There are several of them in the literature. The term merger is a close, proprietary form of merger of two firms, one in which two firms merge into one. A merger is a process in which two companies voluntarily merge [2,20]. It may take the form of a merger. The first concerns the merger of two equivalent undertakings, one of which retains its name, identity and acquires all the assets and liabilities of the purchased undertaking. The second ceases to exist as a separate business unit. In the second case, the merger of two 
enterprises into one new one, which takes place through the merger of share capital with the prior consent of the shareholders. The merger may also be effected by the fact that the new undertaking exchanges its shares under the favorable conditions for those of the companies which are being dissolved. The merger is usually conducted on a voluntary basis by agreement between the shareholders and the boards of the merging companies.

Acquisition is the process of engaging a smaller or economically weaker enterprise with a larger or stronger enterprise. Absorption is the purchase of $51 \%$ or more of the voting shares of the acquirer (acquirer) in the target undertaking (acquirer). This can be done by repurchasing the shares of the target company for cash, by offering bonds, respectively. a new issue of shares which are exchanged for shares of the target undertaking. Ingestion usually has an involuntary, forced character [21,22]. Confronted with the need to adapt to the common market, the emergence of the European Monetary Union and the increasing globalization of markets, European firms have focused strongly on acquisition strategies, especially since the mid-1980s [16]. Acquisition has been addressed by several authors $[23,24]$ in their publications. In general, achieving a synergistic effect can be defined by a well-known equation $1+1=3$. The equation implies that the joint value of the merged companies (in our case, equal to three) should be greater than the sum of individual enterprise values before the merger $(1+1=2)$. It is this difference that increases the value of our business after the merger results from a synergy effect. The ways in which synergies can be achieved include, for example:

1. economies of scale - Cost savings are made by merging selected divisions of both companies, especially the production, distribution and marketing divisions or the entire management. Cost savings while maintaining revenue levels lead to higher profits and, therefore, higher corporate value. This effect is usually higher if they merge companies from the same industry (ie, in a horizontal merger). Merging companies with a different focus may entail even higher costs, especially administrative costs.

2. Financial savings - Business size also increases their financial stability and confidence in banks, making them cheaper and more profitable for lower transaction costs.

3. Differential performance - occurs when management of one company is more efficient than management of the other company, and can increase the value of the other company by more efficient management (eg in the area of costs and revenues).

4. Larger market share - With increasing market share, the firm's negotiating position is usually strengthened against suppliers and customers. Alternatively, there is the possibility to dictate market prices. In this case, however, the Competition Protection Office could have intervened and either the notified M \& A would not allow or could impose conditions or sanctions on the company.

5. knowledge concentration - where the value of the target enterprise depends, in particular, on ownership of know-how and know-how. Small businesses often have some technology or products. However, they do not have such capital to fully exploit the potential of their uniqueness. This can be achieved by joining the large company that will provide it, which will be beneficial for both companies.

However, we should keep in mind that each $M$ \& A performed may not achieve the above synergies. It is usually the company's management, what goals it will try to achieve and whether they can do it. The most common M \& A target is to achieve synergies from economies of scale. For comparison, we can say the division of synergies according to foreign, mostly English, specialized sources. We will most often encounter the following division on [25]:

- Operational synergies, including, for example, economies of scale, higher business growth or greater market share, and higher sales revenue, potentially higher profits.

- Financial synergies that we can combine, in particular, with the stronger financial position of the business and the less costly interest on borrowed foreign capital. 


\section{Determining the value of synergy effects on fusion and acquisition using Model $\mathrm{H}$}

Model $\mathrm{H}$ to determine the value of synergies has been created based on the use of an enterprise's business valuation method that can be included in the yield method of determining the asset's overall value. The model is based on the value of the cash flow in the initial period of the companies to be merged and the rate of growth of this cash flow in future periods (for the two-step model) and the capitalization rates. The evaluation procedure under this model is based on the market values of the A and B companies before the merger and the values of these enterprises after the merger. By comparing the values of merged enterprises without synergies and including synergies, we can calculate the resulting synergistic effect of the merger. The basic data needed to calculate the synergistic effect are shown in Table 1.

Table 1 Basic data needed to calculate the synergistic effect

\begin{tabular}{|l|c|c|c|c|}
\hline Enterprises & A & B & $\begin{array}{c}\text { A+B } \\
\text { without } \\
\text { synergies }\end{array}$ & $\begin{array}{c}\mathbf{A}+\mathbf{B} \\
\text { including } \\
\text { synergies }\end{array}$ \\
\hline Cash Flow at 0 in mill. Eur & 300 & 150 & 450 & 450 \\
\hline Growth rate in the first 5 years in\% & 12,00 & 15,00 & 13,00 & 15,00 \\
\hline Growth rate in subsequent years in\% & 6,00 & 10,00 & 7,33 & 10,00 \\
\hline Capitalization rate (in\%) & 13,00 & 14,00 & 13,33 & 13,33 \\
\hline
\end{tabular}

Source: custom processing

The columns labelled A and B represent data for individual evaluation of both businesses. Zero year cash flow and capitalization rate (i) would be determined from current financial statements and market information. Furthermore, we assume, based on estimates, that enterprises will grow at a constant rate of $12 \%$ (xi) for business A and $15 \%$ (xi) for business in the first five years, and 5\% (xi) for business A and 10\% (xi) ) for business B. We apply this growth rate to the value of cash flow in the zero year to obtain cash flow values (pi) in the first five years and beyond. The calculation of the growth rate of the merged enterprises without synergies is as follows:

1. Calculation of growth rate $(\mathrm{g})$ in the first 5 years in $\%$ for $A+B$ without synergy:

2. Calculation of growth rate $(\mathrm{g})$ in subsequent years in $\%$ for $\mathrm{A}+\mathrm{B}$ without synergy:

$$
g=\frac{\sum_{i=1}^{n} x_{i} \cdot p_{i}}{\sum_{i=1}^{n} p_{i}}=\frac{(0,06 \cdot 300)+(0,10 \cdot 150)}{300+150}=7,33
$$

3. Calculation of capitalization rate (i) for A + B without synergies:

$$
i=\frac{\sum_{i=1}^{n} x_{i} \cdot p_{i}}{\sum_{i=1}^{n} p_{i}}=\frac{(0,13 \cdot 300)+(0,14 \cdot 150)}{300+150}=13,33
$$

The next step is to calculate the future cash flows of individual A and B companies, merged A + B companies without synergies, and merged A + B companies, including synergies. The calculation can be found in Table 2 . 
Table 2 Calculating Future Cash Flow (in millions of Euro)

\begin{tabular}{|c|c|c|c|c|}
\hline Cash Flow 5 years & $\mathbf{A}$ & B & $\begin{array}{c}A+B \\
\text { without synergies }\end{array}$ & $\begin{array}{c}\mathbf{A}+\mathbf{B} \\
\text { including synergies }\end{array}$ \\
\hline 1 & 336 & 173 & 509 & 518 \\
\hline 2 & 376 & 198 & 575 & 595 \\
\hline 3 & 421 & 228 & 650 & 684 \\
\hline 4 & 472 & 262 & 734 & 787 \\
\hline 5 & 529 & 302 & 830 & 905 \\
\hline $\mathrm{CF}$ in subsequent years & 560 & 332 & 892 & 996 \\
\hline
\end{tabular}

Source: custom processing

Now we have all the necessary data to calculate the present values, using the formulas used from the business method of determining the general value of the business. The calculation is done in three points, namely the calculation of the present value of Cash Flow over a period of 5 years, in the second point is the calculation of the continuing value of the company based on Cash flow in the following years. continued value of the company. The calculation of the value of the synergy effect from the merger is in Table 3.

Table 3 Calculation of the synergy value of enterprises A and B (in millions of EUR)

\begin{tabular}{|c|c|c|c|c|c|c|c|c|c|c|c|c|}
\hline \multirow[b]{2}{*}{ Year } & \multicolumn{3}{|c|}{ A Company } & \multicolumn{3}{|c|}{ B Company } & \multicolumn{3}{|c|}{$\begin{array}{c}\mathbf{A}+\mathbf{B} \\
\text { without synergies }\end{array}$} & \multicolumn{3}{|c|}{$\begin{array}{c}\mathbf{A}+\mathbf{B} \\
\text { including synergies }\end{array}$} \\
\hline & KF & CF & SH CF & KF & CF & SH CF & KF & $\mathbf{C F}$ & SH CF & KF & CF & SH CF \\
\hline 1 & 0,88496 & 336 & 297 & 0,87719 & 173 & 152 & 0,88238 & 509 & 509 & 0,88238 & 518 & 457 \\
\hline 2 & 0,78315 & 376 & 294 & 0,76947 & 198 & 152 & 0,77859 & 574 & 575 & 0,77859 & 595 & 463 \\
\hline 3 & 0,69305 & 421 & 292 & 0,67497 & 228 & 154 & 0,68701 & 649 & 650 & 0,68701 & 684 & 470 \\
\hline 4 & 0,61332 & 472 & 289 & 0,59208 & 262 & 155 & 0,60621 & 734 & 734 & 0,60621 & 787 & 477 \\
\hline 5 & 0,54276 & 529 & 287 & 0,51937 & 302 & 157 & 0,53490 & 831 & 830 & 0,53490 & 905 & 484 \\
\hline \multicolumn{3}{|c|}{ SH CF } & 1460 & & & 770 & & & 3298 & & & 2351 \\
\hline \multicolumn{3}{|c|}{ Value Continued (PH) } & 4427 & & & 4194 & & & 8087 & & & 10823 \\
\hline \multicolumn{3}{|c|}{$V \breve{S H}=S H C F+H T$} & 5888 & & & 4964 & & & 11385 & & & 13174 \\
\hline \multicolumn{12}{|c|}{ The value of the synergy effect ( $13174-11385)$} & 1789 \\
\hline
\end{tabular}

Source: custom processing

This calculation is made for each company (A, B) separately, for linked enterprises (A + $\mathrm{B}$ without synergies) and for linked enterprises ( $\mathrm{A}+\mathrm{B}$ including synergies). According to the business method, the market value of company A calculated is EUR 5,888 million. EUR and market value of company B is 4964 mil. Eur. The market value of the connected A + B companies, including synergies, is EUR 13174 million. Eur. The synergistic effect of the merger represents an amount 1789 Eur (13 174-11385).

\section{Achieved results and discussion}


When calculating the value of the synergy effect, the other calculated values also serve as a measure for determining the contractual premium for the purchase of Company B, as can be seen in Table 4. We assume that the net present value of the investment must be positive or equal to zero. If the market value of target company B calculated by us is 4964 mil. EUR and the value of the total effect resulting from M \& A in the amount of 1798 mil. The purchase price should not exceed the sum of these values, ie $6753 \mathrm{mil}$. Eur. The price is based on the market value of company B and the amount of the premium should not exceed the value of the synergy effect.

In practice, besides determining the value of the overall synergy effect of $M \& A$, it is also necessary to focus on determining the value of specific synergies (synergies from sales, synergies from cost savings, synergies from financial savings, etc.). In assessing the value of these partial synergies, we will again base on the plans and estimates that management has to make before executing the M\&A itself. The selected synergies are not the only ones that can be estimated. However, these are the most common economic effects of M\&A and the calculation of their values is based on a similar basis. If we would like to estimate the value of other effects, these models can be easily modified for the given situation [18]. For example, if we would like to estimate the value of tax or financial savings resulting from M\&A, we would use the cost savings value model [9,10]. Figure 1 compares the number of M\&A transactions in CSE (Central and South-Eastern Europe), where we can also compare V4 countries.

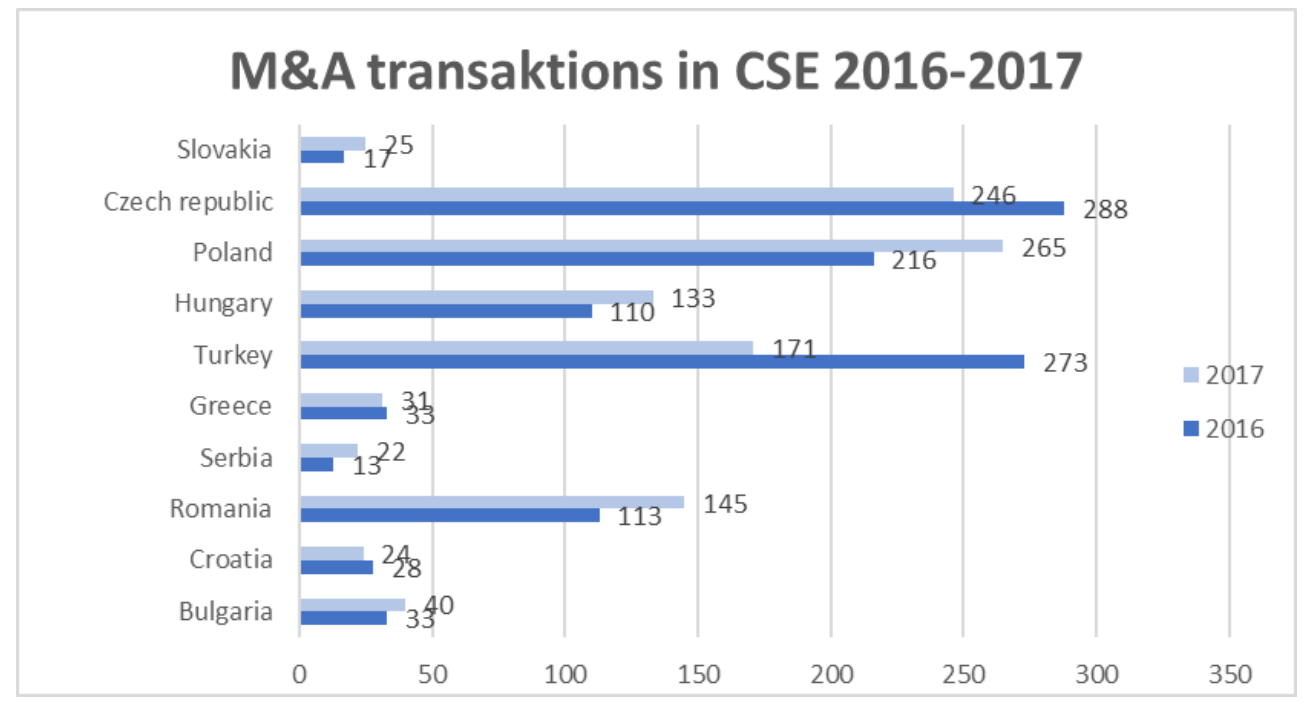

Figure 1 Comparison M\&A transaction in CSE 2016 and 2017

M\&A Barometer from Ernst \& Young provides an overview of M\&A developments and summarizes and analyses publicly available information collected from reputable databases. Methodologically, the M\&A Barometer includes transactions in the private sector. It excludes data on acquisitions of minority interests below $15 \%$, further acquisitions of minority interests by majority shareholders, real estate transactions (except where the target or buyer was a real estate company or real estate fund), capital market transactions (except for transactions that resulted changes in control), acquisitions of licenses, joint ventures, greenfield investments, listed companies for the first time, privatizations, multinationals (their value is ignored in each country but counted), and internal reorganization [7]. The graph compares the number of mergers and acquisitions transactions in CSE (Central and South Eastern Europe), where we can also compare V4 
countries. In comparison with the V4 countries, Slovakia achieved the smallest number of mergers and acquisitions between 2016 and 2017.

Poland was the most active country in terms of deal volume in 2017, closing 265 transactions during the respective period. It was followed by the Czech Republic and Turkey, closing 246 and 171 deals respectively. Although in 2017 the total number of transactions in the CSE market was 1,132, which represents a $2.8 \%$ decline compared with 2016, six of the countries - Bulgaria, Hungary, Poland, Romania, Serbia and Slovenia experienced increased M\&A activity in terms of the number of transactions in 2017. The slight decrease was mainly caused by the significant drop in the volume of deals in Turkey, where the number of closed deals was 171 , representing a $37.4 \%$ decrease compared with 2016.

\section{Conclusion}

World globalization of the economy forces the company to pool capital in order to achieve higher efficiency. With all the variety of reasons and intents to merge businesses, the overriding objective of most of them is to achieve a synergistic effect arising from the complementary activity of the assets of two or more enterprises. The volume of M \& A transactions in Slovakia is decreasing. Practical experience shows that far from all companies achieve the expected effect in the M \& A transaction process.

Assessing the potential synergy is one of the most complicated tasks in analyzing the effectiveness of the merger. The authors propose an express analysis that allows to evaluate the potential synergistic effect and to choose the optimal concept of the functioning of the future society at the decision-making stage. The success of fusion is influenced by many factors. The most important could include managing rationalization, gaining access to new banking techniques, optimizing economies of scale, portfolio diversification, synergy, and last but not least, the way of financing the merger.

Evaluating the success of the merger is very difficult after a few years, but the easiest way is to use different analytical methods and ratios. Indicators need to be tracked and judged in the timeline, and it is important to underline that even slight changes in the level of indicators can identify changes in clientele and changes in the financial market. Prior to a merger, the value of a synergy effect from a future merger can be an important element in decision making.

Currently, the activity on $\mathrm{M} \&$ A markets is declining due to a discrepancy in the actual value of potential sales businesses and their price offered. China, the United States, India, Brazil, Germany and Indonesia remain the largest investment destination, with M \& A being the most common in manufacturing, financial services, the oil and gas industry, and consumer goods. In terms of sectoral orientation, there are horizontal links between enterprises operating in the same industry, vertical links of enterprises operating in one production chain, and conglomerate links of enterprises engaged in business in different sectors in order to diversify business risk.

The volume of M \& A transactions worldwide is growing steadily. Practical experience, however, shows that far from all companies achieve the expected effect in the $M$ \& A transaction process. Assessing the potential synergy is a challenging task in analyzing the effectiveness of the merger. The role of the proposed $\mathrm{H}$ Model is to contribute to determining the effectiveness of mergers based on the quantification of synergy effects.

\section{Acknowledgement}

The paper is the outcome of the grant project of the Ministry of Education of the Slovak Republic KEGA project No.025EU-4/2018 "Systematic knowledge transfer in the field of economic knowledge and forensic expertise. 


\section{References}

1. Berger, P. G. - Ofek, E. Diversification's Effect on Firm Value. Journal of Financial Economics, 37, No. 1, pp. 39 - 65. (1995)

2. Brealey, R.A. - Myers, S. C. Teorie a praxe firemních financí. Praha : Victoria Publishing.(2003)

3. Brunner, R. F. Applied mergers and acquisitions. Hoboken: John Wiley \& Sons Inc., 1029 p. (2004)

4. Damodaran, A. This model estimates the value of synergy in a merger. [cit. 2020-0324]. Dostupné z www: http://pages.stern.nyu.edu/ adamodar/. (2006)

5. Damodaran, A. The Value of Synergy [online]. Stern School of Business. [cit. 2020-0324]. Available from www:

http://pages.stern.nyu.edu/ adamodar/pdfiles/papers/synergy.pdf. (2005).

6. Deyong, R. - Evanoff, D. D. - Molyneux, P. Mergers and Acquisitions of Financial Institutions: A Review of the Literature. Journal of Financial Services Research, 36, No. 2 - 3, pp. 87 - 110. (2009)

7. Ernst \& Young. M\&A Barometer 2017 [online]. [cit. 2020-03- 24] Available from www: https://www.ey.com/Publication/vwLUAssets/ey-csema-barometer2017/\$FILE/ey-csema-barometer-2017.pdf. (2018)

8. Harumová, A et al. Stanovenie hodnoty majetku : hlavné aspekty ekonomickej znaleckej a expertnej činnosti. Bratislava : Iura Edition, Ekonómia. (2008)

9. Harumová, A. Stanovenie hodnoty IV : stanovenie hodnoty synergických efektov Lewes : Ecoletra.com. ISBN 978-1-947099-90-6. (2017)

10. Harumová, A. Teória finančného riadenia holdingu. Lewes : Ecoletra.com. (2019)

11. KPMG International. A new dawn: good deals in challenging times. In: [online]. [cit. 2020-03-

http://www.kpmg.com/CZ/cs/IssuesAndInsights/ArticlesPublications/Pressreleases/D ocument s/KPMG_MA-New-Dawn-2011.pdf. (2011)

12. Královič, J. - Vlachynský, K. Finančný manažment, Bratislava : IURA EDITION. (2002)

13. Lang, L. - Stulz, R. Tobin's q, Corporate Diversification, and Firm Performance. Journal of Political Economy, 102, No. 6, pp. 1248 - 1280. (1994)

14. Lelyveld, I. - Knot, K. Do Financial Conglomerates Create or Destroy Value? Evidence for the EU. Journal of Banking \& Finance, 33, No. 12, pp. 2312 - 2321. (2008)

15. Links, K. V. - Servaes, H. Is Corporate Diversification Beneficial in Emerging Markets? Journal of Financial Management, 31, No. 2, pp. 5 - 31. (2002)

16. Lissauerová, D. Euro and the Process of Constitution of the European Monetary Union. In: Integracja europejska a rynek. PSB-SW Kraków 1999, s. 47 - 62. (1999)

17. Montgomery, C. A. - Wernerfeld, B. Diversification, Ricardian Rents, and Tobin's q. The RAND Journal of Economics, 19, No. 4, pp. 623 - 632. (1998)

18. RAY, Kamal G., Mergers and acquisitions: Strategy, valuation and integration. PHI Learning Private Limited, 870 s. ISBN-978-81-203-3975-0. (2010)

19. Soukupová, J. a kol. Mikroekonomie. Praha: Management Press. (2000) 
20. Smolková, E. Strategická partnerstvá ako fenomén globálnej ekonomiky, Bratislava : Spoločnost' autorov vedeckej a odbornej literatúry - Savol. ISBN 80- 7079-558-1. (2005)

21. Schertzinger, A. Value Creation by European Insurance $M \& A$. [Dissertation Thesis.] Oestrich-Winkel, Germany: European Business School. (2008)

22. Schoenberg, R. Measuring the Performance of Corporate Acquisitions: An Empirical Comparison of Alternative Metrics. British Journal of Management, 17, No. 4, pp. $361-370 .(2006)$

23. Staikouras, S. K. An Event Study Analysis of International Ventures between Banks and Insurance Firms. Journal of International Financial Markets, Institutions and Money, 19, No. 4, pp. 675 - 691. (2009)

24. Stoyanova, R. - Grundl, H. Solvency II: A Driver for Mergers and Acquisitions? The Geneva Papers on Risk and Insurance - Issues and Practice, 39, No. 3, pp. 417 - 439. (2014)

25. Tan, F. Mergers and acquisitions finance. Innovation Ventures. [cit. 2020-03- 24]. Available from www: http:/www.innovationventures.sg/finance-for- entrepreneu rmanagers/mergers---acquisitions-finance. (2019) 